\title{
Peran Kepolisian Resort Ponorogo Dalam Menjaga Stabilitas Politik Dalam Rangka Pilkades Serentak
}

\author{
Irvan Nur Ridho \\ Program Studi Ilmu Pemerintahan \\ E-mail : irvannurridho@gmail.com \\ Yusuf Adam Hilman \\ Progran Studi Ilmu Pemerintahan \\ E-mail : adam_hilman@umpo.ac.id
}

\begin{abstract}
Astraksi.
Peran kepolisian tidak dapat dipisahkan dari sistem sosial masyarakat. Kepolisian mempunyai peran yang penting dalam perkembangan sejarah perkembangan masyarakat. Maka dari itu dari waktu kewaktu peran kepolisian selalu mengalami perubahan seiring dengan perubahan sosial, perubahan politik, dan perubahan industri. Proses demokrasi dewasa semakin kompleks, untuk itu diperlukan peran dari berbagai pihak untuk menjaga stalibitas keamanan dan politik khususnya dari pihak kepolisian. Penelitian ini bertujuan untuk mengetahui dan mendeskripsikan peran kepolisian dalam menjaga stabilitas politik dalam rangka pilkades serentak. Jenis penelitian ini adalah penelitian kualitatif dengan, dengan menggunakan pendekatan library research. Peran kepolisian dalam pelaksanaan tugasnya sebagai penegak hukum dan petugas ketertiban masyarakat mepunyai beberapa peran dalam menjaga stabilitas politik. Upaya represif dan preventif dilakukan untuk menjaga keamanan dan ketertiban masyarakat.
\end{abstract}

Keywords : Peran, Polisi, Stabilitas Politik.

\section{Aabstract.}

The role of the police cannot be separated from the social system of the community. The police have an important role in the development of the history of community development. Therefore from time to time the role of the police always changes along with social change, political change, and industrial change. The process of adult democracy is increasingly complex, so that the role of various parties is needed to maintain security and political stability especially from the police. This study aims to determine and describe the role of the police in maintaining political stability in the context of simultaneous elections. This type of research is qualitatif research, using a library research method. The role of the police in carrying out its duties as law enforcers and public order officers has several roles in maintaining political stability. Repressive and preventive efforts are carried out to maintain public security and order.

Keyword : Role; Police; Political Stability

\section{Pendahuluan.}

Kehadiran Kepolisian tidak dapat dipisahkan dari sistem sosial kemasyarakatan. Peran kepolisian tidak pernah lepas dalam perubahan sosial yang terjadi di dalam masyarakat. Kepolisian dituntut untuk mengikuti perubahan-perubahan sosial, ekonomi, politik dan industri teknologi. Apalagi masyarakat sekarang ini sudah masuk ke dalam revolusi industri 4.0. Oleh karena itu, beban tugas dan peran kekepolisianan senantiasa mengalami perubahan dari masa ke masa. Tugas utama kepolisian dalam perkembangan sejarah berkisar pada penegakkan hukum (law enforcement), memelihara Ketertiban umum (order maintenance atau peacekeeping) serta pelayanan masyarakat (provide service) Dalam bidang kemananan nasional, pemikiran tentang

Irvan Nur Ridho; Yusuf Adam Hilman / POPULIKA/ Vol. 8 No. 2 Tahun 2020 
negara hukum (Rechstaat) bukan negara kekuasaan (Machstaat) menjadi tonggak dasar reformasi di tubuh Kepolisian. Hal ini di tunjukkan dengan pemisahan Kepolisian dengan TNI pada tahun 1999, melalui instruksi presiden RI pada tangal 1 April 1999. Dengan tujuan bisa menjadi ujung tombak dalam penegakan hukum dan keamanan.

Tugas dan fungsi Kepolisian diatur di dalam Pasal 2 Undang-Undang Nomor 2 Tahun 2002 Tentang Kepolisian Negara Republik Indonesia, diatur mengenai fungsi Kepolisian, yang menyatakan bahwa: "Fungsi kepolisian adalah salah satu fungsi pemerintahan negara di bidang pemeliharaan keamanan dan ketertiban masyarakat, penegakan hukum, perlindungan, pengayoman, dan pelayanan kepada masyarakat".

Fungsi Kepolisian dibidang pemeliharaan keamanan dan ketertiban masyarakat (Kamtibmas) adalah suatu wujud pelaksanaan tugas-tugas yang memiliki tanggung jawab untuk menciptakan suatu keadaan yang tertib, tenteram, dan teratur dalam kehidupan masyarakat sehari-hari. Sebagai petugas utama yang berperan dalam mewujudkan keamanan dan ketertiban, Kepolisian memegang kewenangan dan kendali penuh terhadap pencapaian tujuan terwujudkan Kamtibmas yang kondusif.

Tahun 2019 merupakan tahun politik yaitu dimulai dari pemilu presiden dan wakil presiden dan calon legislatif, hingga terselenggaranya Pemilihan Kepala Desa serentak. Maka tidak dapat dipungkiri segala bentuk kegiatan masyarakat lebih banyak bernuansa politik baik secara terang-terangan maupun secara terselubung.

Pilkades yang sudah diatur oleh perundang-undangan untuk saat ini sangat sulit terselenggara dengan lancar dan berkualitas karena faktor-faktor kepentingan politik, kepentingan untuk ingin berebut kekuasaan ketimbang hakikat yang diingini oleh pilkades yaitu pemerintahan desa yang legitimate (Widjaja, 1996, hal. 24)

Pelaksanaan pilkades tidak jarang menuai kericuhan dan konflik, Timbulnya konflik pemilihan kepala Desa yang berkepanjangan akibat fanatisme, redahnya kesadaran masyrakat terhadap hukum dan kerasnya konfrontasi pendukung calon kepala desa yang secara tatap muka saling memperjuangkan kemenangan calon masing-masing. Bahkan kadang telah melupakan nilai dari demokrasi dan melunturkan nilai etika yang selama ini tertanam dalam masyarakat desa. Konflik diawali dengan ketidak puasan, berbagai rasa curiga atas kemenangan calon terpilih.

Data yang diperoleh, akan ada 198 desa yang melaksanakan pilkades pada tanggal 20 Mei 2019 di wilayah resort Ponorogo. Maka dari itu, akan diperlukan segenap pihak untuk melancarkan hajat pilkades serentak ini. Kepolisian sebagai bagian dari aparat penegak hukum, pengayom, pelindung dan pelayan masyarakat dalam memelihara kamtibmas dituntut melaksanakan tugasnya untuk mengamankan jalannya pesta demokrasi, baik dari pendaftaran calon sampai akhir dari penghitungan suara. (Ahmad Taufik, 2018, hal. 16)

Namun, keterlibatan kepolisian sangat terbatas karena dalam Pilkades, karena sudah dibuat lembaga untuk menyelenggarakan pilkades yang dibuat oleh Bupati kemudian di delegasikan kepada BPD sebagai penyelengara pemilihan kepala desa ditingkat lokal. Kemudian BPD menunjuk panitia penyelenggara pilkades. Maka dari itu untuk meredam permasalahan yang timbul di masyarakat di wilayah resort Ponorogo. Peran kepolisian diperlukan untuk menjaga stabilitas keamanan dalam rangka pilkades serentak. Penelitian ini bertujuan untuk menganalisis peran kepolisian dalam pilkades serentak.

\section{Metode.}

Metode penelitian yang digunakan dalam penelitian ini adalah metode penelitian kualitatif. Metode kualitatif menurut Bogdan dan Taylor adalah metode penelitian yang menghasilkan data kualitatif berupa data deskriptif yang merupakan kata-kata yang ditulis dn

Irvan Nur Ridho; Yusuf Adam Hilman / POPULIKA/ Vol. 8 No. 2 Tahun 2020 
perilaku yang diamati (moleong, 2011, hal. 4)

Sedangkan jenis pendekatan yang digunakan adalah Metode ini adalah metode dengan cara mengumpulkan data pustaka, literasi, dan mencatat serta mengolah bahan penelitian. Penulis menggunakan analisis kritis yang kuat pada sumber data yang diperoleh dengan teori atau konsep untuk menginterpretasikan hasil penelitiannya menjadi sebuah pembahasan ilmiah. (Zed, 2004, hal. 2)

\section{Hasil Dan Pembahasan.}

UU No. 6 Tahun 2014 Pasal 31 menentukan, bahwa pemilihan kepala desa dilaksanakan secara serentak diseluruh wilayah kabupaten/kota. Pemerintahan daerah kabupaten/kota menetapkan kebijakan pelaksanaan pemilihan kepala desa secara serentak dengan peraturan daerah kabupaten/kota. Kemudian didalam Pasal 40 PP No. 43 Tahun 2014 tentang Peraturan Pelaksanaan UU No. 6 Tahun 2014 tentang Desa, ditentukan bahwa pemilihan kepala desa secara serentak dapat dilaksanakan bergelombang paling banya 3 (tiga) kali dalam jangka waktu 6 (enam) tahun.

Dalam hal terjadi kekosongan jabatan kepala desa dalam penyelenggaraan pemilihan kepala desa serentak, bupati/walikota menunjuk penjabat kepala desa. Penjabat kepala desa berasal dari pegawai negri sipil dilingkungan pemerintah daerah kabupaten/kota. Pemilihan Kepala Desa secara serentak diseluruh wilayah Kabupaten/Kota dimaksudkan untuk menghindari hal negatif dalam pelaksanaannya. Pemilihan Kepala Desa secara serentak mempertimbangkan jumlah Desa dan kemampuan biaya pemilihan yang dibebankan pada Anggaran Pendapatan dan Belanja Daerah Kabupaten/Kota sehingga dimungkinkan pelaksanaannya secara bergelombang sepanjang diatur dalam Peraturan Daerah Kabupaten/Kota.

Sebagai akibat dilaksanakannya kebijakan pemilihan Kepala Desa secara serentak, dalam Undang-Undang ini diatur mengenai pengisian jabatan Kepala Desa yang berhenti dan diberhentikan sebelum habis masa jabatan. Pemilihan Kepala Desa secara serentak dilaksaakan melalui beberapa tahapan, yag disebutkan dalam Pasal 6 Permendagri Nomor 112 Tahun 2014 tetang Pemilihan Kepala Desa, menyebutkan pelaksanaan pemilihan kepala desa melalui tahapan Persiapan, Pencalonan, Pemungutan Suara dan Penetapan. Sebelum dilakukan pemilihan Kepala Desa, Badan Permusyawaratan Desa memberitahukan kepada Kepala Desa mengenai akan berakhirnya masa jabatan Kepala Desa secara tertulis 6 (enam) bulan sebelum masa jabatan berakhir. Badan Permusyawaratan Desa membentuk panitia pemilihan Kepala Desa. Panitia pemilihan Kepala Desa bersifat mandiri dan tidak memihak. Panitia pemilihan Kepala Desa terdiri atas unsur perangkat Desa, lembaga kemasyarakatan, dan tokoh masyarakat Desa.

Kepala Desa dipilih secara langsung oleh dan dari penduduk Desa warga negara Republik Indonesia yang memenuhi persyaratan dengan masa jabatan 6 (enam) tahun terhitung sejak tanggal pelantikan. Kepala Desa dapat menjabat paling banyak 3 (tiga) kali masa jabatan secara berturut-turut atau tiak secara berturut-turut.

\section{Kedudukan Kepolisian Dalam Menjaga Stabilitas Politik.}

Kepolisian dimata masyarakat adalah sebagai petugas yang terus menerus memberikan perhatian terhadap pemecahan soal-soal kejahatan dan memberikan pelayanan publik dalam penanganan kejahatan. Dari pengertian tersebut menandakan bahwa pandangan masyarakat terhadap keberadaan Kepolisian hanyalah terbatas pada pemecahan-pemecahan masalah kejahatan, padahal tidak hanya sampai disitu pengertian tentang Kepolisian. Arti Kepolisian itu sendiri timbul karena kedudukan dan peranannya yang mengimplikasikan tanggung jawab yang besar terutama dalam bidang keamanan dan ketertiban sosial. Kepolisian senantiasa hadir untuk mengisi dinamika perubahan masyarakat, dan untuk mengantisipasi setiap potensi konflik yang

Irvan Nur Ridho; Yusuf Adam Hilman / POPULIKA/ Vol. 8 No. 2 Tahun 2020 
menyertainya. (Banurusman, 1995, hal. 1)

Mengenai keamanan umum, dapat dikatakan bahwa kita dapat mencapainya dengan penegakan hukum, masyarakat akan merasa aman. Kepolisian adalah penegakan hukum sebagaimana pengertian Kepolisian adalah penegak hukum yang hidup, melalui Kepolisian bertujuan untuk mengamankan dan melindungi masyarakat. (Sitompul, Edward Syah Pernong, 2003, hal. 33)

Selanjutnya Kepolisian dengan peranannya sebagai pengayom keamanan yang ruang lingkupnya tidak terbatas pada masalah kejahatan memiliki andil besar terehadap stabilitas masyarakat. Sementara itu tanpa adanya dukungan masyarakat belum dalam melaksanakan fungsinya, Kepolisian akan berhasil mencapai sasaran yang diharapkan. Ini membuktikan bahwa Kepolisian memiliki pertautan dengan masyarakat dimana Ia hidup atau dengan kata lain, timbal balik antar keduannya dapat menyatukan tujuan sasaran yang hendak dicapai. Sehubungan dengan hal diatas tercantum dalam Undan-undang No 2 tahun 2002 tentang Kepolisian Negara menjelaskan bahwa, kepolisian adalah alat revolusi dalam rangka pembangunan Nasionl, semula berencana untuk menuju tercapainya masyarakat adil dan makmur bersama berdasarkan Pancasila.

Berdasarkan uraian diatas, dapat disimpulkan kedudukan Kepolisian dalam stabilitas politik adalah sebagai penegak hukum, pengayom dan penjaga ketertiban masyarakat. Kepolisian mempunyai tugas dan fungsi dalam menjaga stabilitas politik dalam pembangunan nasional. Keterkaitanya dengan pilkades adalah dalam pembangunan nasional pilkades merupakan bagian penting yang mendasar dan menjadi pijakan awal terjadinya pembangunan nasional di bidang politik.

\section{Peran Kepolisian Dalam Menjaga Stabilitas Politik Dalam Rangka Pilkades Serentak.}

Kepolisian tidak bisa bergerak sendirian, dibutuhkan peran serta masyarakat dalam menjaga keamanan dan ketertiban dimasyarakat. Sehingga kepolisian perlu menggiatkan kembali peran masyarakat dalam kegiatan Poskamling bekerja sama dengan tokoh pemuda, tokoh masyarakat, tokoh agama dan seluruh elemen yang berada di masyarakat. Bahkan apabila dari kepolisian kurang aktif ataupun tidak netral yang mengakibatkan kegaduhan antar masyarakat pada saat pilkades, maka dapat dilaporkan.

Kepolisian dalam menghadapi tahun politik ini lebih cocok untuk mengedepankan soft power dalam memelihara Kamtibmas. Pengamanan diaplikasikan dalam fungsi represif dan preventif. Langkah ini dilakukan sebagai prakondisi untuk memantapkan situasi keamanan dan ketertiban masyarakat yang kondusif. Kepolisian bekerjasama dengan fungsi intelijen melaksanakan deteksi dini, pemetaan terhadap kerawanan yang dapat menimbulkan konflik, melakukan penggalangan komponen masyarakat selanjutnya memberdayakan masyarakat melalui kegiatan sosialisasi dan mengelola informasi dari masyarakat.

Seperti yang disampaikan oleh (Ahmadi, 2018, hal. 69) bahwa penyelenggara tugas kepolisian yang mendasari kepada pemahaman bahwa untuk menciptakan kondisi aman dan tertib tidak mungkin dilakukan oleh Kepolisian sepihak sebagai subjek dan masyarakat sebagai objek, melainkan harus dilakukan bersama oleh kepolisian dan masyarakat dengan cara memberdayakan masyarakat melalui kemitraan kepolisian dan warga mayarakat, sehingga secara bersama-sama mampu mendeteksi gejala yang dapat menimbulkan permasalahan di masyarakat, mampu mendapatkan solusi untuk mengantisipasi permasalahannya dan mampu memelihara keamanan serta ketertiban di lingkungannya.

Kepolisian yang bertugas di kewilayahan sangat menentukan keberhasilan Pilkades serentak 2019. Kepolisian harus memahamai cara-cara mencegah konflik di masyarakat menjelang dan setelah pelaksanaan Pilkades. Karena tugas mereka sangat vital, maka dituntut harus bisa merangkul warga dan memberikan pemahaman tentang pentingnya menjaga kemanan

Irvan Nur Ridho; Yusuf Adam Hilman / POPULIKA/ Vol. 8 No. 2 Tahun 2020 
serta sanggup mendinginkan suhu politik di wilayah tugasnya. Untuk memperoleh hasil optimal, (Sinungwati, 2018) menyebutkan agar anggota kepolisian diwajibkan menyambangi minimal dua rumah warga perhari, dalam sambang tersebut menyampaikan materi - materi antara lain masalah hukum, dan menanamkan kepercayaan masyarakat kepada Kepolisian. Wajib memberikan nomor telepon baik nomor telepon pribadinya maupun nomor telepon kepolsian yang bisa dihubungi masyarakat jika membutuhkan kehadiran Kepolisian ataupan bila ingin memberikan informasi kepada kepolisian baik ke tingkat Polsek, Polres maupun Polda. Memang tidak mudah untuk dilaksanakan namun apabila dilaksanakan dengan ikhlas maka keberhasilan akan cepat tercapai. Dan tentunya masyarakat akan semakin percaya kepada Kepolisian dan akan berperan aktif dalam menjaga keamanan dan ketertiban masyarakat pada saat ataupun diluar proses Pilkades serentak. Selain yang disebutkkan diatas, juga banyak cara yang dilakukan kepolisian untuk menciptakan Pilkades serentak 2019 ini berjalan dengan baik dan damai yaitu menggelar sosialisasi dan Bimtek tentang Pilkades kepada panitia penyelenggara pilkades, melaksanakan kegiatan sambang kunjung ke kantor Lurah dan RT/RW untuk menyampaikan pesan-pesan kamtibnas dalam rangka antisipasi Pilkades 2019, dan melakukan koordinasi dengan Ketua Panitia penyelenggara pilkades, dari beberapa implementasi tugas mengamankan dan menertibkan masyarakat tersebut untuk mensuseskan Pilkades serentak 2019.

Maka sangat jelas peran kepolisian sangat berguna dan menguntungkan, karena selain tugas tersebut sudah diatur dalam UUD 1945 dan dilaksanakan pada waktu Pilkades serentak 2019 yang rentan adanya konflik maka sangat tepat peran kepolisian untuk membantu dalam hal kemanan dan ketertiban dimasyarakat.

\section{Kesimpulan.}

Peran kepolisian dalam Pilkades serentak 2019 sangat penting karena keamanan, ketertiban, dan tegaknya hukum, serta terbinanya ketentraman merupakan salah satu prasyarat terselenggaranya proses pembangunan nasional, Pilkades serentak 2019 merupakan bagian dari cara untuk mewujudkan pembangunan nasional, maka Polisi Republik Indonesia tentunya dapat menangkal, mencegah, dan menanggulangi segala bentuk pelanggaran hukum dan bentuk-bentuk gangguan lainnya yang dapat meresahkan masyarakat dalam proses berjalanya pilkades serentak 2019, sekalipun kepolisian bukan bagian dari lembaga penyelenggara Pilkades serentak 2019.

\section{Daftar Pustaka.}

Ahmad Taufik, H. (2018). Tata Kelola Konflik Dalam Pemilihan Kepala Desa diKabupaten Bantaeng. Jurnal Politikom Indonesiana, Vol.3 No.1 Juli 2018.

Ahmadi, S. (2018). Penerapan Polmas Oleh Babinkamtibmas Dalam Pembinaan Siskamling. Jurnal pamator volume 11 edisi 1 April 2018.

Amiruddin, Z. (2004). Pengantar Metode Penelitian Hukum. Jakarta: PT. Radja Grafindo Persada.

Banurusman. (1995). Kepolisian Masyarakat dan Negara. Yogyakarta : Biagraf Publishing.

Kartodirjo, S. (1992). Pesta Demokrasi di Pedesaan Studi Kasus Pemilihan Kepala Desa di Jawa Tengah dan DIY. Aditya Media, 11.

Moleong, L. J. (2011). Metodologi Penelitian Kualitatif Edisi Revisi. Bandung: PT. Remaja Rosdakrya. 
Nasroen. (1995). Daerah Otonomi Tingkat Terbawah. jakarta : Beringin Trading Company.

Sinungwati, S. (2018). Retrieved mei 5, 2019, from humas polres bantul: http://humaspolresbantul.blogspot.co.id/2014/02/babinkamtibmas-dan-pemilu-2014.html

Sitompul, Edward Syah Pernong. (2003). Hukum Kepolisian Indonesia (SatuBunga Rampai). Bandung: Transito.

Widjaja, H. (1996). pemerintah desa dan administrasi desa. Jakarta: PT. Raja Grafindo.

Zed, M. (2004). Metode Penelitian Kepustakaan. Jakarta: Yayasan Obor Nasional. 